\title{
Assessing the endocrine disrupting potentials and genotoxicity in environmental samples from Taiwanese rivers
}

\author{
Pei-Hsin Chou $^{1 *}$ (D), Chien-Hsun Chen ${ }^{1}$, Kuang-Yu Chen ${ }^{1}$, Fung-Chi Ko ${ }^{2,3}$, Tsung-Ya Tsai ${ }^{1}$ and Yi-Po Yeh ${ }^{1}$
}

\begin{abstract}
Background: Surface waters receive a variety of organic pollutants via wastewater discharge, and sediment represents a sink for hydrophobic contaminants. In this study, we used in vitro yeast-based reporter gene assays and a Bacillus subtilis Rec-assay to examine the occurrence of endocrine disrupting activities and genotoxic potentials in samples collected from three Taiwanese rivers. Levels of 51 polycyclic aromatic hydrocarbons (PAHs) in muscles of fish captured from same rivers were also analyzed to assess in vivo pollution of PAHs.

Results: Antagonist activities for androgen receptor and retinoid $X$ receptor (RXR) were detected in river water extracts at environmentally relevant concentrations., and sediment extracts exhibited RXR agonist, RXR antagonist, and genotoxic potentials concurrently. $\Sigma 16$ PAHs in fish muscles ranged from $44.9-242.4 \mathrm{ng} \mathrm{g}^{-1}$ dry weight, representing 38 to 59\% of the total 51 PAHs concentrations, and methylated PAHs of low molecular weight PAHs were often detected as well.

Conclusion: Taiwanese river sediment samples concomitantly exhibited RXR disrupting potentials and genotoxic activities, whereas RXR agonist and antagonist activities were simultaneously detected in several dry-season sediment extracts. PAH levels in fish muscles were categorized as minimally polluted by aromatic compounds, nonetheless, the presence of methylated PAHs in muscles samples may be of concern owing to the higher toxic potentials than their parent compounds.
\end{abstract}

Keywords: Endocrine disrupting potential, Genotoxicity, Yeast-based reporter gene assays, Rec-assay, Polycyclic aromatic hydrocarbons

\section{Background}

Concerns over the presence of anthropogenic pollutants in the environment have been raised with the development of trace analytical techniques. Among numerous contaminants, conventional organic pollutants such as polycyclic aromatic hydrocarbons (PAHs) have drawn much attention owing to their environmental persistence and various adverse effects to organisms [1]. Along with the routine

\footnotetext{
* Correspondence: phchou@mail.ncku.edu.tw

${ }^{1}$ Department of Environmental Engineering, National Cheng Kung University, 1, University Road, Tainan 701, Taiwan

${ }^{2}$ Graduate Institute of Marine Biology, National Dong Hwa University, 2, Houwan Road, Pingtung 944, Taiwan

${ }^{3}$ National Museum of Marine Biology and Aquarium, 2, Houwan Road, Pingtung 944, Taiwan
}

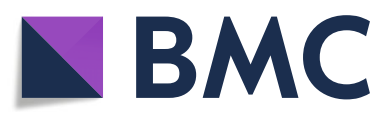

(c) The Author(s). 2019 Open Access This article is distributed under the terms of the Creative Commons Attribution 4.0 International License (http://creativecommons.org/licenses/by/4.0/), which permits unrestricted use, distribution, and reproduction in any medium, provided you give appropriate credit to the original author(s) and the source, provide a link to the Creative Commons license, and indicate if changes were made. The Creative Commons Public Domain Dedication waiver carry out mixture toxicity assessment since a diversity of pollutants are concomitantly present in the aquatic environment. Nowadays, the progress in establishing recombinant cell bioassays enables time- and cost-efficient toxicity evaluation of substances showing similar toxic responses in environmental matrices. In vitro assays such as Ames test, SOS/umu test, micronucleus test, or comet assay are well known as useful tools for mutagenicity and genotoxicity screening of environmental samples [2-9]. In vivo measurement of DNA adducts in fish has been used as biomarkers of genotoxicant exposure as well [10-13]. For example, fish collected from PAH-contaminated sites showed significantly higher mean levels of DNA adducts in hepatic tissues \footnotetext{
(http://creativecommons.org/publicdomain/zero/1.0/) applies to the data made available in this article, unless otherwise stated.
} 
than those from a relatively non-polluted site in Québec, Canada [12]. A high amount of DNA adducts was also detected in fish caught from French Atlantic Coast two months after an oil spill [13].

In addition to persistent organic pollutants, emerging contaminants such as endocrine disrupting compounds (EDCs) are also of environmental concern. EDCs are chemicals that may act like (anti-)hormones or disrupt the synthesis and metabolism of hormones to alter the normal function of endocrine systems [14, 15]. Contaminants that interact with androgen receptor (AR) and estrogen receptor (ER) represent an important category of EDCs owing to their possible interference with reproductive function. Bioanalytical tools such as the yeast estrogen/androgen screen assays, the MCF-7 cell proliferation assay, and the chemically activated luciferase expression assays using rat/ mouse cells transfected with AR/ER-regulated luciferase reporter genes have been broadly used to examine estrogenic/androgenic activities in surface water and wastewater effluents [16-19]. While sex hormone mimics in the environment have been comprehensively investigated, concerns are raised over new classes of EDCs. A battery of in vitro bioassays have thus been developed and used for detecting contaminants capable of binding to different receptors, such as thyroid hormone receptor (TR), glucocorticoid receptor (GR), mineralocorticoid receptor (MR), progesterone receptor (PR), retinoid X receptors (RXRs), etc. [20-24].

Over the past few decades, high levels of organic pollutants have been detected in Taiwan's aqueous environment, suggesting a potential threat to aquatic biota [25-29]. Herein, mixture effects of a diversity of EDCs and genotoxicants present in Taiwanese river samples were investigated using yeast-based reporter gene assays and Bacillus subtilis Rec-assay, respectively. PAH levels in fish were also measured as a biological indicator for river pollution. Our objectives were to explore the occurrence of different toxic potentials in Taiwan's aquatic environment and to assess the degree of PAH contamination in fish collected from downstream of Taiwanese rivers.

\section{Methods \\ Reagents}

Reagents used in this study were all of analytical grades. Dimethyl sulfoxide (DMSO), methanol, acetone, hexane, and anhydrous sodium sulfate were obtained from Merck (USA). Glucose, galactose, $17 \beta$-estradiol (17 $\beta$ E2), 4-hydroxytamoxifen (OHT), dihydrotestosterone (DHT), flutamide (FLU), triiodothyronine (T3), 9-cis retinoic acid $(9 c \mathrm{RA})$, chlorophenol red- $\beta$-D-galactopyranoside (CPRG), $o$-nitrophenyl- $\beta$-D-galactopyranoside
(ONPG), and 4-nitroquinoline-1-oxide (4-NQO) were purchased from Sigma (USA).

\section{Collection of river water, sediment, and fish samples}

Water, sediment, and fish samples were collected from three rivers that flow through densely populated areas in southern Taiwan, including Yanshuei River (5 sites, Y1-Y5, sediment of Y4 was not available), Erren River (7 sites, E1E7), and Agondian River (3 sites, A1-A3) (Fig. 1 and Additional file 1: Table S1). Fish were captured downstream of each river (Y5, E4, A3) with the help of local fishermen, and were transported to laboratory on ice as soon as possible. Fish samples collected were mainly pollution-tolerant benthic species that could survive at low dissolved oxygen concentration (Additional file 1: Table S2).

\section{Pretreatment of river water, sediment, and fish samples}

Each water sample $(1 \mathrm{~L})$ was filtered through $0.60 \mu \mathrm{m}$ glass fiber filters (Advantec, Japan) and solid phaseextracted using two conditioned Sep-Pak ${ }^{\circ}$ Plus Environmental C18 Cartridges (Waters, USA). Each cartridge was eluted with $3 \mathrm{~mL}$ of methanol and $1 \mathrm{~mL}$ of DMSO, and the eluates were concentrated by vacuum evaporation (CVE-3100, EYELA, Japan) and redissolved in DMSO.

Each sediment (Sed) sample was homogenized to pass through a 20 mesh sieve following freeze-drying in a freeze dryer (FDU-1200, EYELA, Japan) for at least $24 \mathrm{~h}$. Then, $10 \mathrm{~g}$ of each pretreated sample was soxhletextracted with anhydrous sodium sulfate-added hexane: acetone $(1: 1,200 \mathrm{~mL})$ solution for $24 \mathrm{~h}$. After extraction, the extract solution was added with $0.5 \mathrm{~g}$ anhydrous sodium sulfate and was evaporated to less than $3-5 \mathrm{~mL}$ by rotary evaporation (EYELA, Japan). Extractant was further purified by passing through an alumina oxide column and desulfurized by adding activated copper. The final extractant was concentrated using a purified nitrogen stream to $1 \mathrm{~mL}$ of DMSO (concentration: $10000 \mathrm{mg}$ Sed-equivalent $\mathrm{mL} \mathrm{DMSO}^{-1}$ ) [26].

Fish dissection was carried out following species identification and length/weight measurement (Additional file 1: Table S2). Muscles of four fish from Y5 (Y5F1Y5F4), 2 fish from E4 (E4F1, E4F2), and 4 fish from A3 (A3F1-A3F4) were collected and subjected to PAH analysis. Fish muscles were freeze-dried and extracted with dichloromethane in an accelerated solvent extractor (ASE-300, Dionex, USA). Lipid content was determined by gravimetric method and then was removed as stated in previous research [30].

\section{Endocrine disrupting activity evaluation}

$\mathrm{ER}, \mathrm{AR}, \mathrm{RXR}$, and TR disrupting activities of river samples were investigated using yeast-based reporter gene assays carried out as described in previous studies 


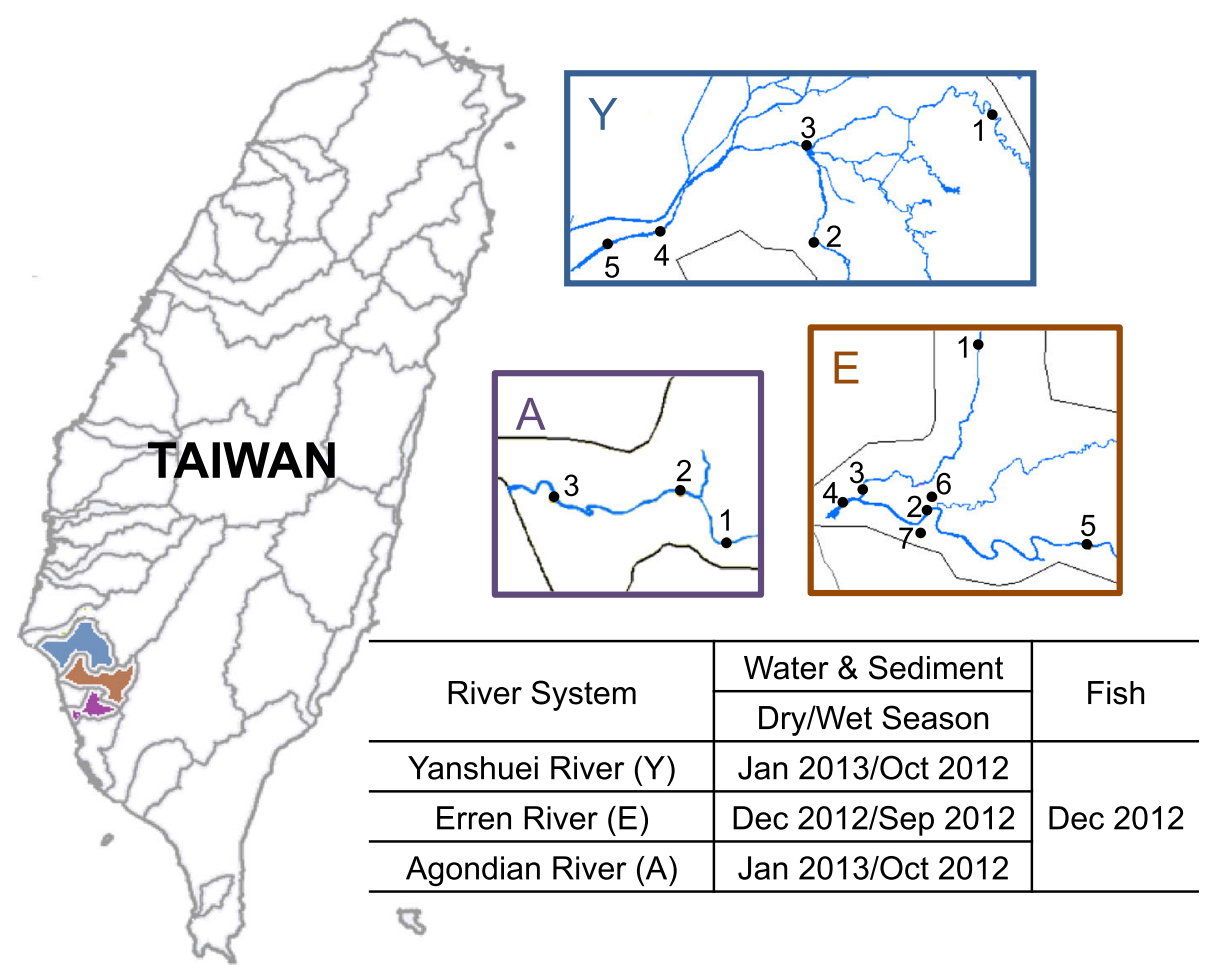

Fig. 1 Sampling locations, site numbers, and schedule for water, sediment, and fish samples collected from Yanshuei River (Y), Erren River (E), and Agondian River (A) of Taiwan

[22-24, 26-28]. In short, an overnight recombinant yeast culture was mixed with a sample, a negative control (DMSO), or a positive control (17 $\beta$-E2, DHT, $9 c$ RA, T3, OHT, FLU) in a 96-well microplate, and was incubated at $32 / 30^{\circ} \mathrm{C}$ for $72 / 18 \mathrm{~h}$. Each experiment was carried out in triplicate. The medium was pre-mixed with $0.3 \mathrm{nM} 17 \beta$-E2 and CPRG solution for testing ER antagonist activity, and the medium was added with $25 \mathrm{nM}$ DHT/9cRA/T3 for testing AR/RXR/TR antagonist activities. The concentrations of $17 \beta-\mathrm{E} 2$, DHT, $9 c \mathrm{RA}$, and T3 used in the antagonist assays were approximately the half maximal effective concentrations $\left(\mathrm{EC}_{50}\right)$ in the agonist assays (Additional file 1: Figure S1). The cell suspension was mixed with ONPG solution after sample exposure and was further incubated at $37^{\circ} \mathrm{C}$ for $1 \mathrm{~h}$ for analyzing AR/RXR/TR disrupting activities. The absorbances at $620 \mathrm{~nm}\left(\mathrm{~A}_{620}\right), 540 \mathrm{~nm}\left(\mathrm{~A}_{540}\right), 595 \mathrm{~nm}$ $\left(\mathrm{A}_{595}\right)$, and $405 \mathrm{~nm}\left(\mathrm{~A}_{405}\right)$ were measured by a microplate absorbance spectrophotometer (xMark, Bio-Rad, USA) for calculating agonist/antagonist activity (ER agonist activity: fold induction of DMSO $\left(\mathrm{FI}_{\mathrm{DMSO}}\right)=[($ $\left.\left.\left.\mathrm{A}_{540}\right)_{\text {SAMPLE }}-\left[\left(\mathrm{A}_{620}\right)_{\text {SAMPLE }}-\left(\mathrm{A}_{620}\right)_{\text {DMSO }}\right)\right]\right] /\left(\mathrm{A}_{540}\right)_{\text {DMSO }}$, ER antagonist activity: $\mathrm{FI}_{0.3} \mathrm{nM}$ E2 $(\%)=\left[\left(\mathrm{A}_{540}\right)_{\mathrm{SAM}-}\right.$ $\mathrm{PLE}-\left[\left(\mathrm{A}_{620}\right)_{\text {SAMPLE }}-\left(\mathrm{A}_{620}\right)_{0.3} \mathrm{nM}\right.$ E2 $\left.]\right] /\left(\mathrm{A}_{540}\right)_{0.3} \mathrm{nM} \quad \mathrm{E} 2 \times$ $100 \%, \mathrm{AR} / \mathrm{RXR} / \mathrm{TR}$ agonist activity: $\mathrm{FI}_{\mathrm{DMSO}}=\left(\mathrm{A}_{405} /\right.$ $\left.\mathrm{A}_{595}\right)_{\text {SAMPLE }} /\left(\mathrm{A}_{405} / \mathrm{A}_{595}\right)_{\mathrm{DMSO}}, \mathrm{AR} / \mathrm{RXR} / \mathrm{TR}$ antagonist activity: $\mathrm{FI}_{25} \mathrm{nM}$ DHT/9cRA/T3 $(\%)=\left(\mathrm{A}_{405} / \mathrm{A}_{595}\right)_{\text {SAMPLE }} /$ $\left(\mathrm{A}_{405} / \mathrm{A}_{595}\right)_{25} \mathrm{nM}$ DHT/9cRA/T3 $\left.\times 100 \%\right)$. FLU, 17 $\beta$-E2, and OHT equivalent concentrations (EQ) were calculated using the concentration-activity curves of corresponding standard compounds (Additional file 1: Figure S1).

\section{Genotoxicity testing}

The Bacillus subtilis Rec-assay was applied to evaluate genotoxic potential in river sediment samples [31]. In brief, the survivals of a recombination proficient (Rec+) strain $\mathrm{H} 17\left(\mathrm{arg}^{-}, \mathrm{trp}^{-}, \mathrm{recE}^{+}\right)$and a recombination deficient strain (Rec-) M45 ( $\mathrm{arg}^{-}, \operatorname{trp}^{-}$, $\mathrm{recE}^{-}$) were compared to assess possible genotoxic effects of tested samples. 4-NQO and DMSO were used as positive and negative controls, respectively. Experiments were carried out as previously described [25], and genotoxicity was calculated as $R_{50}$, which is the ratio of median inhibitory concentrations $\left(\mathrm{IC}_{50}\right)$ of Rec+ and Rec $-\left(\mathrm{R}_{50}=\mathrm{IC}_{50, \mathrm{Rec}+} / \mathrm{IC}_{50, \text { Rec- }-}\right)$.

\section{Analysis of PAH levels in fish muscles}

Concentrations of 51 non-substituted and methylated PAHs in fish muscle samples collected at Y5, E4, and A3 were determined as described [32] using a Varian 3800 GC/Saturn 4000 ion trap mass spectrometry (GC-MS) equipped with a $30 \mathrm{~m}$ Varian VF-5 ms capillary column (i.d.: $0.25 \mathrm{~mm}$, film thickness: $0.25 \mu \mathrm{m}$ ) under the selected ion monitoring mode. Perdeuterated PAH surrogates $\left(\mathrm{d}_{8}\right.$-napthalene, $\mathrm{d}_{10^{-}}$-fluorene, $\mathrm{d}_{10^{-}}$-fluoranthene, $\mathrm{d}_{12^{-}}$ 
perylene) were added to the procedural blanks, whereas $\mathrm{d}_{10}$-acenaphthene, $\mathrm{d}_{10}$-phenanthrene, $\mathrm{d}_{12}$-benz $[a]$ anthracene, $\mathrm{d}_{12}$-benzo[a]pyrene, and $\mathrm{d}_{12}$-benzo $[g, h, i]$ perylene were used as internal standards and added to each sample prior to analysis. The method detection limits (MDLs) and recoveries of each PAH are listed in Additional file 1: Table S3, whereas PAH levels were not corrected for surrogate recoveries.

\section{Results and discussion}

Endocrine disrupting potentials in river water and sediment extracts

Figure 2 shows the AR/ER/RXR/TR disrupting activities elicited by river water extracts at environmentally relevant concentrations. More than 13 and $30 \%$ of the river water extracts demonstrated significant antagonist activities for AR and RXR (Fig. 2a and c, lower-left region, $\mathrm{FI}_{25} \mathrm{nM}$ DHT/9cRA $<75 \%$ ), respectively, whereas ER/TR disrupting activities were only detected in 10-fold and 5fold concentrated water extracts (Additional file 1: Figure S2). The highest ER agonist, ER antagonist, and AR antagonist activities were found in the dry-season water extracts of E3, Y2 (17 $\beta$-E2- EQ: $34.6 \mathrm{ng} \mathrm{L}^{-1}$, OHTEQ: $\left.65.5 \mu \mathrm{g} \mathrm{L}^{-1}\right)$ and the wet-season water extract of A1 (FLU-EQ: $3377.5 \mu \mathrm{g} \mathrm{L}^{-1}$ ), respectively. Although the values of $17 \beta$-E2-EQ, OHT-EQ, and FLU-EQ were lower than what have been detected in other sites of Taiwanese rivers [27, 28], our results suggested the pseudopersistence of EDCs interfering with AR/ER signaling in river waters of Taiwan.

RXR agonist and antagonist activities were found in dry- and wet-season sediment extracts with the detection frequencies of 32 and 36\%, respectively (Fig. 3a), whereas TR disrupting activities were rarely detected in sediment extracts (Fig. 3b). In particular, all dry-season sediment extracts of Agondian river (A1-A3), E1, and E7 elicited RXR agonist and antagonist activities concomitantly (upper-left region, $\mathrm{FI}_{\mathrm{DMSO}}>1.5$ and $\mathrm{FI}_{25} \mathrm{nM}$ $9 c \mathrm{cA}<75 \%$, Fig. 3a), while the co-existence of agonistic/ antagonistic substances may lead to lower estimation of the disrupting potentials. Additionally, dry-season sediment extracts collected at Y5, E4, and A3 also exhibited significant RXR antagonist activities, suggesting that RXR antagonists may accumulate in downstream river sediments.

In the past decades, diverse anthropogenic substances have been identified as potential RXR agonists or antagonists. For example, organotins used as ingredients in antifouling paints have been well-known as potent ligands to activate human RXR [33], whereas tributyltin, tetrabutyltin, tripropyltin, tricyclohexyltin, and triphenyltin were shown to induce ligand-
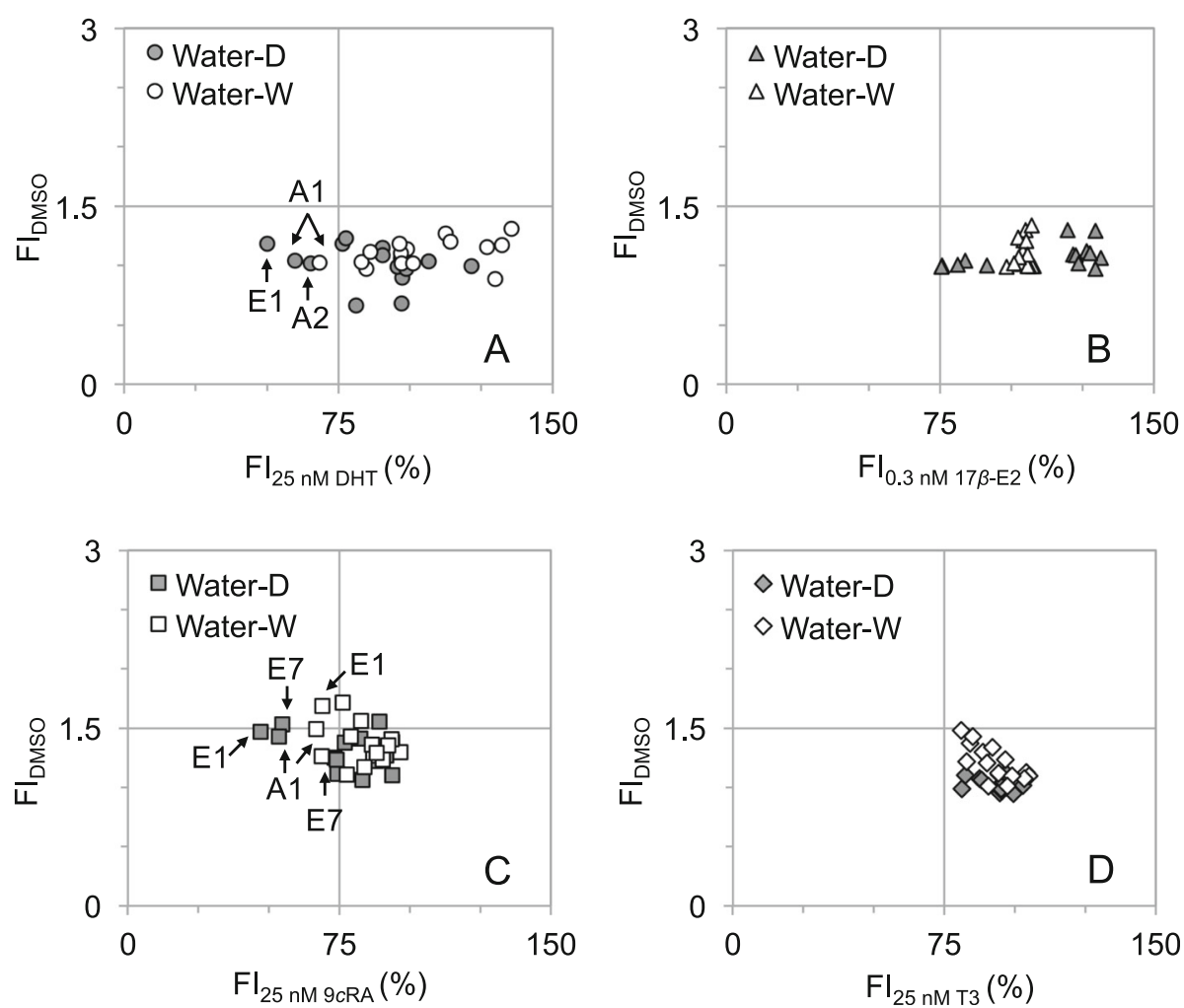

Fig. 2 a AR $\mathbf{b} E R \mathbf{c} T R \mathbf{d} R X R$ agonist and antagonist activities elicited by dry-season river water extracts (Water-D) and wet-season river water extracts (Water-W) at environmentally relevant concentrations 

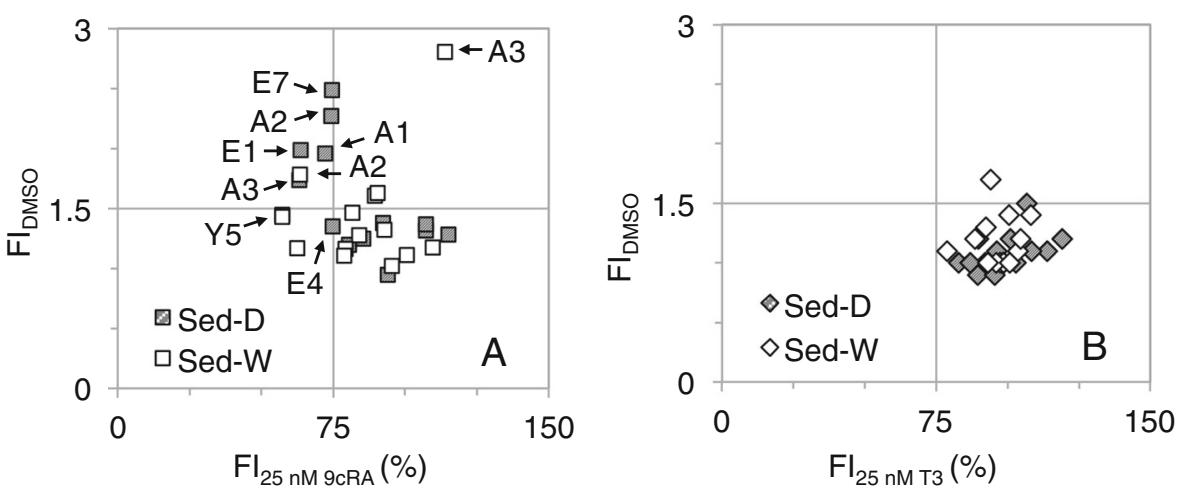

Fig. 3 a RXR $\mathbf{b}$ TR agonist and antagonist activities elicited by dry-season river sediment extracts (Sed-D) and wet-season river sediment extracts (Sed-W) (concentration: $100 \mathrm{mg}$ Sed-equivalent $\mathrm{mL} \mathrm{DMSO}^{-1}$ for agonist activity measurement and $50 \mathrm{mg}$ Sed-equivalent $\mathrm{mL} \mathrm{DMSO}^{-1}$ for antagonist activity measurement)

dependent transactivation of Thais clavigera RXR [34]. RXR agonist activities of various monohydroxylated polychlorinated biphenyls congeners (OH-PCBs), in particular tri- or tetra-chlorinated $\mathrm{OH}-\mathrm{PCBs}$ were also identified recently [35]. By contrast, the plastic additive bisphenol A (BPA) and its chlorination byproducts have been demonstrated to exhibit RXR antagonist activities [36]. Several statins (fluvastatin, pitavastatin) and nonsteroidal anti-inflammatory drugs ( $R$-etodolac, sulindac) were recognized as RXR antagonists as well [37-39]. In the aquatic environment of Taiwan, the contaminants mentioned above or their parent compounds (i.e. PCBs) have been extensively detected [27-29, 40, 41]. For instance, butyltins and phenyltins have been found in Taiwan's river sediment (ND-465 and ND-787 $\mathrm{ng} \mathrm{g}^{-1}$ ) and fish muscle samples (11-6860 and ND-1458 $\mathrm{ng} \mathrm{g}^{-1}$ ), where as phenyltins were dominant in freshwater environments possibly owing to illegal pesticidal use [40]. The RXR agonist/antagonist activities in Taiwanese river samples may be partially attributed to the occurrence of these recalcitrant contaminants.

\section{Genotoxicity in river sediment extracts}

Rec-assay analysis revealed that significant genotoxic activities $\left(R_{50}>1.5\right)$ were detected in dry-season sediment extracts of Y5, E1, E4, E7, A1, A3, and wet-season sediment extract of E7 (Fig. 4 and Additional file 1: Figure S3). Figure 4 shows the concentration-survival curves of Rec+ and Rec- strains exposed to different concentrations of river downstream sediment extracts (Y5, E4, A3), and the sediment extracts of $\mathrm{A} 3$ exhibited the lowest $\mathrm{IC}_{50}$ values for both strains. It is also noteworthy that the dry- and wet-season sediment extracts of A2 (Additional file 1: Figure S3) and wet-season sediment extracts of Y5 and A3 (Fig. 4) may be polluted cytotoxic substances owing to the detection of cytotoxicity instead of genotoxicity. Our previous work also reported that genotoxic activities were found in the sediment extracts of Y5, E1, E4, E7, and A1A3 collected during different years [25], suggesting the constant input of genotoxicants into these sites.

Table 1 lists the RXR/TR disrupting potentials and genotoxic activities found in the sediment extracts analyzed in this study. It is interesting that the sediment extracts showing genotoxicity concurrently exhibited RXR disrupting activities. Several RXR agonists and antagonists, such as previously mentioned organotins or BPA and its analogs have been reported as environmental genotoxicants $[42,43]$. BPA is a typical EDC widely known to possess estrogenic, anti-androgenic, and genotoxic potencies. Its concentrations in river waters and suspended solids of E1 have been reported to be as high as 725 and $12.3 \mu \mathrm{g} \mathrm{L}^{-1}$, respectively [27]. Although BPA concentrations in sediment extracts are not analyzed in this study, its hydrophobic nature may lead to high accumulation in river sediments, which may contribute to the RXR disrupting activities and genotoxic potentials found in sediment extracts.

\section{PAHs in fish captured downstream of Taiwanese rivers} Levels of 51 PAHs (including 16 USEPA priority PAHs) in muscles of fish samples collected from Y5, E4, and A3 were investigated in this study. As shown in Fig. 5, concentrations of $\Sigma 16 \mathrm{PAHs}$ in fish muscles varied from 44.9-242.4 $\mathrm{ng} \mathrm{g}^{-1}$ dry weight (dw) (11.0-52.4 $\mathrm{ng} \mathrm{g}^{-1}$ wet weight (ww)), constituting 38 to $59 \%$ of the total PAHs concentrations $\left(81.0-518.5 \mathrm{ng} \mathrm{g}^{-1} \mathrm{dw}, 19.9-88.4 \mathrm{ng} \mathrm{g}^{-1}\right.$ ww). The National Oceanic and Atmospheric Administration has classified the concentrations of aromatic compounds in tissue samples into four categories, which are not contaminated $\left(<10 \mathrm{ng} \mathrm{g}^{-1} \mathrm{ww}\right)$, minimally contaminated (10-99 $\left.\mathrm{ng} \mathrm{g}^{-1} \mathrm{ww}\right)$, moderately contaminated (100-1000 $\left.\mathrm{ng} \mathrm{g}^{-1} \mathrm{ww}\right)$, and highly contaminated (> 1000 $\left.\mathrm{ng} \mathrm{g}^{-1} \mathrm{ww}\right)$ [44]. Total PAH levels in the muscle samples 

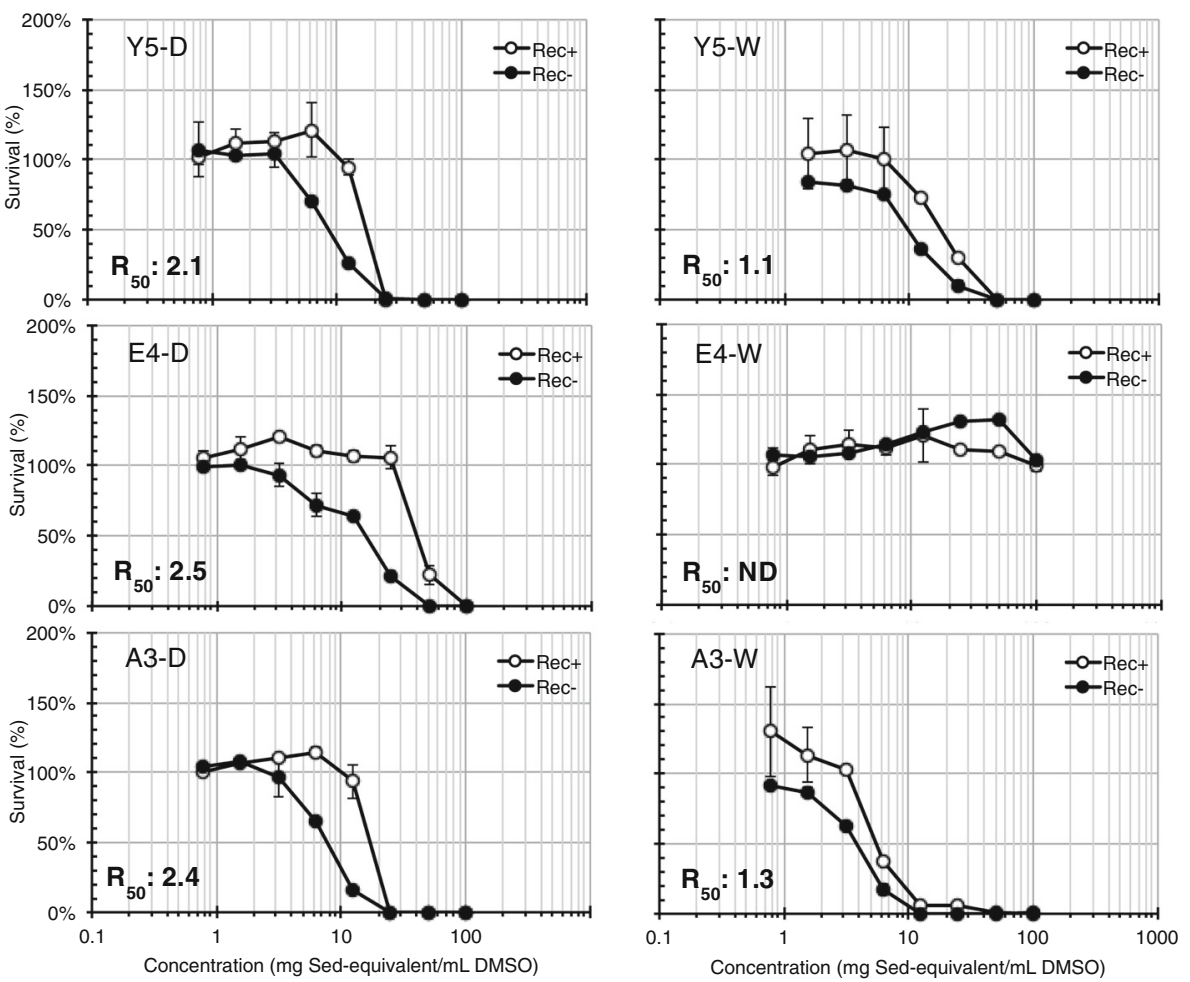

Fig. 4 Concentration-survival rates of Rec+ and Rec-strains exposed to river sediment extracts of Y5, E4, and A3 (left: dry-season sediment extracts (D), right: wet-season sediment extracts $(W)$ ). $R_{50}>1.5$ indicates significant genotoxic activity (ND: no detectable bacterial inhibition, $\mathrm{IC}_{50, \text { Rec+ }}$ and $\mathrm{IC}_{50, \text { Rec- }}$ were greater than $100 \mathrm{mg}$ Sed-equivalent $\mathrm{mL} \mathrm{DMSO}{ }^{-1}$ )

Table 1 RXR/TR agonist activity ( $\left.\mathrm{FI}_{\text {DMSO }}\right)$, antagonist activity $\left(\mathrm{FI}_{25 \mathrm{nM}}\right.$ 9cRA/T3 $\left.(\%)\right)$, and genotoxicity $\left(\mathrm{R}_{50}\right)$ of sediment extracts of Yanshuei River, Erren River, and Agodian River of Taiwan

\begin{tabular}{|c|c|c|c|c|c|c|c|c|c|c|}
\hline \multirow[t]{3}{*}{ Site } & \multicolumn{4}{|c|}{ RXR Disrupting Activity } & \multicolumn{4}{|c|}{ TR Disrupting Activity } & \multirow{2}{*}{\multicolumn{2}{|c|}{ Genotoxicity $R_{50}$}} \\
\hline & \multicolumn{2}{|c|}{$\mathrm{Fl}_{\text {DMSO }}{ }^{* 1}$} & \multicolumn{2}{|c|}{$\mathrm{Fl}_{25 \mathrm{nM}}$ 9cRA $(\%)^{* 2}$} & \multicolumn{2}{|c|}{$\mathrm{Fl}_{\text {DMSO }}{ }^{* 1}$} & \multicolumn{2}{|c|}{$\mathrm{Fl}_{25 \text { nM T3 }}(\%)^{* 2}$} & & \\
\hline & $\mathrm{Dry}^{* 3}$ & $\mathrm{Wet}^{* 4}$ & Dry & Wet & Dry & Wet & Dry & Wet & Dry & Wet \\
\hline Y1 & 1.2 & 1.5 & $81 \%$ & $82 \%$ & 1.0 & 1.2 & $83 \%$ & $89 \%$ & $\mathrm{ND}^{* 5}$ & ND \\
\hline Y2 & 0.9 & 1.1 & $94 \%$ & $79 \%$ & 1.0 & 1.3 & $87 \%$ & $92 \%$ & ND & ND \\
\hline Y3 & 1.4 & $1.6^{* 7}$ & $92 \%$ & $91 \%$ & 1.1 & 1.4 & $96 \%$ & $101 \%$ & ND & ND \\
\hline Y5 & 1.4 & 1.2 & $57 \%$ & $62 \%$ & 1.2 & 1.4 & $101 \%$ & $108 \%$ & 2.1 & 1.1 \\
\hline E1 & 2.0 & 1.6 & $64 \%$ & $89 \%$ & 1.0 & 1.0 & $92 \%$ & $99 \%$ & 1.8 & $>1.25^{* 6}$ \\
\hline E2 & 1.3 & 1.1 & $115 \%$ & $101 \%$ & 1.0 & 1.0 & $103 \%$ & $98 \%$ & ND & ND \\
\hline E3 & 1.2 & 1.2 & $85 \%$ & $110 \%$ & 1.1 & 1.1 & $114 \%$ & $104 \%$ & ND & ND \\
\hline E4 & 1.4 & 1.3 & $75 \%$ & $84 \%$ & 1.2 & 1.0 & $119 \%$ & $99 \%$ & 2.5 & ND \\
\hline E5 & 1.3 & 1.0 & $107 \%$ & $95 \%$ & 0.9 & 1.0 & $90 \%$ & $96 \%$ & ND & ND \\
\hline E6 & 1.4 & 1.2 & $107 \%$ & $79 \%$ & 1.0 & 1.0 & $96 \%$ & $93 \%$ & ND & ND \\
\hline E7 & 2.5 & 1.4 & $75 \%$ & $57 \%$ & 1.5 & 1.2 & $108 \%$ & $105 \%$ & 1.8 & 2.9 \\
\hline A1 & 2.0 & 1.3 & $72 \%$ & $93 \%$ & 1.1 & 1.0 & $108 \%$ & $101 \%$ & 1.8 & ND \\
\hline A2 & 2.3 & 1.8 & $74 \%$ & $63 \%$ & 0.9 & 1.1 & $95 \%$ & $79 \%$ & 1.3 & 1.2 \\
\hline A3 & 1.7 & 2.8 & $63 \%$ & $114 \%$ & 1.2 & 1.7 & $90 \%$ & $94 \%$ & 2.4 & 1.3 \\
\hline
\end{tabular}

${ }^{*} 1$ : sample concentration was $10 \mathrm{mg}$ Sed-equivalent $\mathrm{mL} \mathrm{DMSO}^{-1}$; ${ }^{*}$ : sample concentration was $5 \mathrm{mg}$ Sed-equivalent $\mathrm{mL} \mathrm{DMSO}{ }^{-1}$; 3 : dry season; ${ }^{*} 4$ : wet season; *5: no detectable bacterial inhibition, $\mathrm{IC}_{50}$, Rec + and IC $\mathrm{C}_{50}$, Rec- were greater than the highest concentrations in the dilution series; ${ }^{*} 6$ : $I C_{50}$, Rec + was greater than the highest concentration in the dilution series; *7: Numbers in boldface are $\mathrm{Fl}_{\mathrm{DMSO}}>1.5, \mathrm{~F}_{\mathrm{I} 25 \mathrm{nM} 9 \mathrm{9CR} / \mathrm{T3}}(\%)<75 \%$, and $\mathrm{R}_{50}>1.5$ 


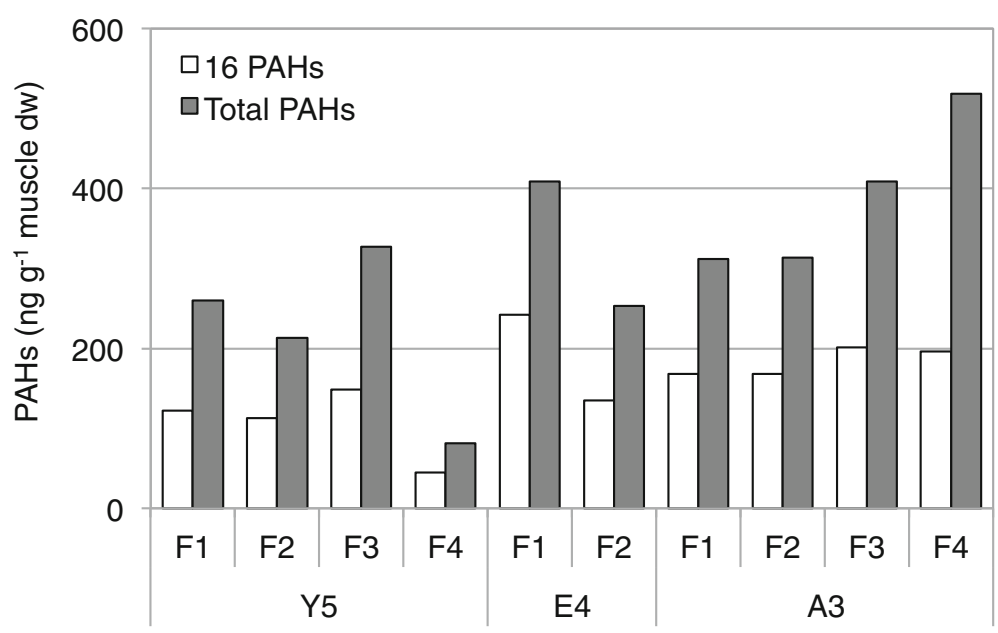

Fig. 5 Summed concentrations of 16 USEPA priority PAHs (16 PAHs) and total summed concentrations of 51 PAHs (Total PAHs) in muscle samples of fish collected at $Y 5, E 4$, and $A 3$

analyzed in this study could be categorized as minimally polluted by PAHs. Moreover, the average PAH concentration of four fish from A3 were significantly higher than that of fish from Y5 ( $p<0.05, t$-test), which corresponded to the higher genotoxicity/cytotoxicity detected in the sediment extracts of A3.

Levels of $\Sigma 16$ PAHs were further compared to those detected in fish muscle samples from other countries. The concentrations of $\Sigma 16$ PAHs in muscles of fish from Taiwanese rivers were comparable to those in fish tissues from Ghana $\left(58-453 \mathrm{ng} \mathrm{g}^{-1}\right.$ $\mathrm{dw}$ ) but higher than those in fish tissues from Italy (1.3-13.3 $\left.\mathrm{ng} \mathrm{g}^{-1} \mathrm{dw}\right)$, Spain (3-40 $\left.\mathrm{ng} \mathrm{g}^{-1} \mathrm{dw}\right)$, Nigeria (8.8-26.1 $\left.\mathrm{ng} \mathrm{g}^{-1} \mathrm{dw}\right)$, and Canada (11-116 $\left.\mathrm{ng} \mathrm{g}^{-1} \mathrm{dw}\right)$ [45-50]. Among individual PAHs, higher mean concentrations of low molecular weight PAHs (LMW-PAHs, 2to 4-rings), such as naphthalene, phenanthrene, dibenzothiophene, and pyrene were detected at $75.0 \pm 52.7$, $38.2 \pm 20.2,19.9 \pm 11.3 \mathrm{ng} \mathrm{g}^{-1}$, and $17.7 \pm 9.3 \mathrm{ng} \mathrm{g}^{-1} \mathrm{dw}$, respectively. Our results were similar to other studies that LMW-PAHs originated from petrogenic sources were identified as the predominant compounds in a diversity of fish species collected from different countries [45-50].

Several methylated derivatives of legacy and heterocyclic PAHs were found at higher frequencies and levels as well, such as 2-methylnaphthalene (14.3 \pm $\left.7.8 \mathrm{ng} \mathrm{g}^{-1} \mathrm{dw}\right), 1,6$-dimethylnaphthalene $(9.4 \pm 4.6 \mathrm{ng}$ $\left.\mathrm{g}^{-1} \mathrm{dw}\right), \quad 2$-methylphenanthrene $\quad\left(11.0 \pm 6.3 \mathrm{ng} \mathrm{g}^{-1}\right.$ $\mathrm{dw})$, 1-methylphenanthrene $\left(9.1 \pm 5.3 \mathrm{ng} \mathrm{g}^{-1} \mathrm{dw}\right), 1$ methylanthracene $\left(10.6 \pm 5.6 \mathrm{ng} \mathrm{g}^{-1} \mathrm{dw}\right)$, and 4,6 dimethyldibenzothiophene $\left(25.3 \pm 14.6 \mathrm{ng} \mathrm{g}^{-1} \quad \mathrm{dw}\right)$. Methylated PAHs have been shown to elicit potent disrupting activities for ER and aryl hydrocarbon receptor, and their hydroxymethyl derivatives have also been suggested to be potential carcinogens [5153]. More research should be undertaken to assess the potential risk of methylated PAHs in edible fish species.

\section{Conclusion}

Sediment samples collected from three polluted Taiwanese rivers concomitantly exhibited RXR disrupting potentials and genotoxic activities. By contrast, river water samples only showed AR/RXR antagonist activities at environmentally relevant concentrations. Noteworthily, RXR agonist and antagonist activities were simultaneously detected in several dry-season sediment extracts, suggesting higher disrupting activities were present in these samples. PAH levels in fish muscle samples fall into the category of minimally polluted by aromatic compounds, however, the detection of methylated PAHs may be of concern owing to the higher toxic potentials than their parent compounds.

\section{Supplementary information}

Supplementary information accompanies this paper at https://doi.org/10. 1186/s41021-019-0140-9.

Additional file 1: Table S1. Basic information of Yanshuei River, Erren River, and Agondian River ${ }^{*}$. Table S2. Biological parameters of the fish captured at downstream of Yanshuei River, Erren River, and Agondian River. Table S3. Method detection limits (MDLs) and recoveries of target PAHs investigated in this study. Figure S1. Concentration-activity curves of agonist/antagonist compounds for AR (DHT/FLU), ER (17 $\beta-E 2 / O H T)$, $R X R(9 c R A)$, and TR (T3). Figure S2. (A) AR (B) ER (C) RXR (D) TR agonist/ antagonist activities elicited by 10-/5-fold concentrated dry-season river water extracts (Water-D) and wet-season river water extracts (Water-W). Figure S3. Concentration-survival rates of Rec+ and Rec-strains exposed to genotoxic standard 4-NQO and dry-/wet-season (D/W) sediment extracts of $E 1, E 7, A 1$, and $A 2$. 


\section{Abbreviations}

AR: Androgen receptor; EDCs: Endocrine disrupting compounds; ER: Estrogen receptor; GC-MS: Gas chromatography-mass spectrometry; PAHs: polycyclic aromatic hydrocarbons; RXR: Retinoid X receptor; TR: Thyroid hormone receptor

\section{Acknowledgements}

The authors are grateful to Prof. Han-You Lin and his group from National Cheng Kung University, Taiwan (present affiliation: National Taiwan Unversity) for performing fish dissection. We also thank Prof. Tomonari Matsuda from Kyoto University, Japan, Prof. Takashi Yagi, and Prof. Masanobu Kawanishi from Osaka Prefecture University, Japan, for providing the recombinant strains.

\section{Authors' contributions}

PC designed the study, analyzed the data, and prepared the manuscript. CC, $\mathrm{KC}$, and TT perfomred the collection of river water and sediment samples, and carried yeast reporter gene assays and genotoxicity tests. FC supervised the PAH analysis. $\mathrm{KC}$ and $\mathrm{YY}$ analyzed PAH levels in fish muscles using GCMS. All authors read and approved the final manuscript.

\section{Funding}

This work was supported by the fundings from the Ministry of Science and Technology, Taiwan (NSC 100-2221-E-006-037-MY2 and MOST 106-2628-E-006-003-MY3).

\section{Availability of data and materials}

Data sharing is not applicable to this article as no datasets were created or analyzed during this study.

\section{Ethics approval and consent to participate}

Not applicable.

\section{Consent for publication}

Not applicable.

\section{Competing interests}

The authors declare that they have no competing interests.

Received: 30 October 2019 Accepted: 13 December 2019

Published online: 30 December 2019

\section{References}

1. Kolpin DW, Furlong ET, Meyer MT, Thurman EM, Zaugg SD, Barber LB, Buxton HT. Pharmaceuticals, hormones, and other organic wastewater contaminants in U.S. streams, 1999-2000: a national reconnaissance. Environ Sci Technol. 2002;36(6):1202-11.

2. Ames BN, McCann J, Yamasaki E. Methods for detecting carcinogens and mutagens with the salmonella/mammalian-microsome mutagenicity test. Mutat Res. 1975;31(6):347-64.

3. Oda Y, Nakamura S, Oki J, Kato T. Evaluation of the new system (umu-test) for the detection of environmental mutagens and carcinogens. Mutat Res. 1985:147(5):219-29.

4. Schmid W. The micronucleus test. Mutat Res. 1975;31(1):9-15.

5. Cotelle S, Ferard JF. Comet assay in genetic ecotoxicology: a review. Environ Mol Mutagen. 1999;34(4):246-55.

6. Hayashi M. The micronucleus test-most widely used in vivo genotoxicity test. Genes Environ. 2016;38:18.

7. Oda Y. Development and progress for three decades in umu test systems. Genes Environ. 2016;38:24.

8. Sofuni T. Evolution of genotoxicity test methods in Japan. Genes Environ. 2017;39:15.

9. Kato M, Sugiyama K, Fukushima T, Miura Y, Awogi T, Hikosaka S, Kawakami K, Nakajima M, Nakamura M, Sui H, Watanabe K, Hakura A. Negative and positive control ranges in the bacterial reverse mutation test: JEMS/BMS collaborative study. Genes Environ. 2018:40:7.

10. Pampanin DM, Brooks SJ, Grøsvik BE, Le Goff J, Meier S, Sydnes MO. DNA adducts in marine fish as biological marker of genotoxicity in environmental monitoring: the way forward. Mar Environ Res. 2017;125:49-62.
11. Sarkar A, Ray D, Shrivastava AN, Sarker S. Molecular biomarkers: their significance and application in marine pollution monitoring. Ecotoxicology. 2006;15(4):333-40

12. El Adlouni C, Tremblay J, Walsh P, Laqueux J, Bureau J, Laliberte D, Keith G, Nadeau D, Poirier GG. Comparative study of DNA adducts levels in white sucker fish (Catostomus commersoni) from the basin of the St. Lawrence River. Mol Cell Biochem. 1995;148(2):133-8.

13. Amat A, Burgeot T, Castegnaro M, Pfohl-Leszkowicz A. DNA adducts in fish following an oil spill exposure. Environ Chem Lett. 2006;4(2):93-9.

14. Auriol M, Filali-Meknassi Y, Tyagi RD, Adams CD, Surampalli RY. Endocrine disrupting compounds removal from wastewater, a new challenge. Process Biochem. 2006;41(3):525-39.

15. Petrie B, Barden R, Kasprzyk-Hordern B. A review on emerging contaminants in wastewaters and the environment: current knowledge, understudied areas and recommendations for future monitoring. Water Res. 2015:72:3-27.

16. Kawanishi M, Takamura-Enya T, Ermawati R, Shimohara C, Sakamoto M, Matsukawa K, Matsuda T, Murahashi T, Matsui S, Wakabayashi K, Watanabe T, Tashiro Y, Yagi T. Detection of genistein as an estrogenic contaminant of river water in Osaka. Environ Sci Technol. 2004:38(23):6424-9.

17. Nelson J, Bishay F, van Roodselaar A, Ikonomou M, Law FCP. The use of in vitro bioassays to quantify endocrine disrupting chemicals in municipal wastewater treatment plant effluents. Sci Total Environ. 2007;374(1):80-90.

18. Houtman CJ, Van Houten YK, Leonards PE, Brouwer A, Lamoree MH, Legler J. Biological validation of a sample preparation method for ER-CALUX bioanalysis of estrogenic activity in sediment using mixtures of xenoestrogens. Environ Sci Technol. 2006;40(7):2455-61.

19. Houtman CJ, Sterk SS, van de Heijning MP, Brouwer A, Stephany RW, van der Burg B, Sonneveld E. Detection of anabolic androgenic steroid abuse in doping control using mammalian reporter gene bioassays. Anal Chim Acta. 2009:637(1-2):247-58

20. Svobodová $K$, Cajthaml T. New in vitro reporter gene bioassays for screening of hormonal active compounds in the environment. Appl Microbiol Biotechnol. 2010;88(4):839-47.

21. Leusch FD, Neale PA, Hebert A, Scheurer M, Schriks MC. Analysis of the sensitivity of in vitro bioassays for androgenic, progestagenic, glucocorticoid, thyroid and estrogenic activity: suitability for drinking and environmental waters. Environ Int. 2017;99:120-30.

22. Shiizaki K, Asai S, Ebata S, Kawanishi M, Yagi T. Establishment of yeast reporter assay systems to detect ligands of thyroid hormone receptors a and $\beta$. Toxicol in Vitro. 2010;24(2):638-44.

23. Shiizaki K, Yoshikawa T, Takada E, Hirose S, Ito-Harashima S, Kawanishi M, Yagi T. Development of yeast reporter assay for screening specific ligands of retinoic acid and retinoid $X$ receptor subtypes. J Pharmacol Toxicol Methods. 2014;69(3):245-52.

24. Ito-Harashima S, Shiizaki K, Kawanishi M, Kakiuchi K, Onishi K, Yamaji R, Yagi T. Construction of sensitive reporter assay yeasts for comprehensive detection of ligand activities of human corticosteroid receptors through inactivation of CWP and PDR genes. J Pharmacol Toxicol Methods. 2015;74:41-52.

25. Chou P-H, Liu T-C, Ko F-C, Liao M-W, Yeh H-M, Yang T-H, Wu C-T, Chen C-H, Tsai T-Y. Occurrence of aryl hydrocarbon receptor agonists and genotoxic compounds in the river systems in southern Taiwan. Chemosphere. 2014; 107:257-64

26. Chen $\mathrm{C}-\mathrm{H}$, Chou P-H, Kawanishi M, Yagi T. Occurrence of xenobiotic ligands for retinoid $X$ receptors and thyroid hormone receptors in the aquatic environment of Taiwan. Mar Pollut Bull. 2014;85(2):613-8.

27. Chou P-H, Lin Y-L, Liu T-C, Chen K-Y. Exploring potential contributors to endocrine disrupting activities in Taiwan's surface waters using yeast assays and chemical analysis. Chemosphere. 2015;138:814-20.

28. Chen K-Y, Chou P-H. Detection of endocrine active substances in the aquatic environment in southern Taiwan using bioassays and LC-MS/MS. Chemosphere. 2016;152:214-20.

29. Hung CC, Gong GC, Jiann KT, Yeager KM, Santschi PH, Wade TL, Sericano JL, Hsieh HL. Relationship between carbonaceous materials and polychlorinated biphenyls (PCBs) in the sediments of the Danshui River and adjacent coastal areas. Taiwan Chemosphere. 2006;65:1452-61.

30. Ko FC, We NY, Chou LS. Bioaccumulation of PBDEs in stranded cetaceans from Taiwan coastal waters. J Hazard Mater. 2014;277:127-33.

31. Takigami H, Matsui S, Matsuda T, Shimizu Y. The Bacillus subtilis rec-assay: a powerful tool for the detection of genotoxic substances in the water environment. Prospect for assessing potential impact of pollutants from stabilized wastes. Waste Manag. 2002;22(2):209-13. 
32. Hsieh HY, Huang KC, Cheng JO, Lo WT, Meng PJ, Ko FC. Environmental effects on the bioaccumulation of PAHs in marine zooplankton in Gaoping coastal waters, Taiwan: concentration, distribution, profile, and sources. Mar Pollut Bull. 2019;144:68-78.

33. Baker AH, Watt J, Huang CK, Gerstenfeld LC, Schlezinger JJ. Tributyltin engages multiple nuclear receptor pathways and suppresses osteogenesis in bone marrow multipotent stromal cells. Chem Res Toxicol. 2015;28(6): 1156-66.

34. Urushitani H, Katsu Y, Kagechika H, Sousa ACA, Barroso CM, Ohta Y, Shiraishi $H$, Iguchi T, Horiguchi T. Characterization and comparison of transcriptional activities of the retinoid $X$ receptors by various organotin compounds in three prosobranch gastropods; Thais clavigera, Nucella lapillus and Babylonia japonica. Aquat Toxicol. 2018;199:103-15.

35. Kamata R, Nakajima D, Shiraishi F. Measurement of the agonistic activities of monohydroxylated polychlorinated biphenyls at the retinoid $X$ and retinoic acid receptors using recombinant yeast cells. Toxicol in Vitro. 2019;57:9-17.

36. Li N, Jiang W, Ma M, Wang D, Wang Z. Chlorination by-products of bisphenol $A$ enhanced retinoid $X$ receptor disrupting effects. J Hazard Mater. 2016:320:289-95.

37. Kolluri SK, Corr M, James SY, Bernasconi M, Lu D, Liu W, Cottam HB, Leoni LM, Carson DA, Zhang XK. The R-enantiomer of the nonsteroidal antiinflammatory drug etodolac binds retinoid $X$ receptor and induces tumor-selective apoptosis. Proc Natl Acad Sci U S A. 2005;102(7):2525-30.

38. Zhou H, Liu W, Su Y, Wei Z, Liu J, Kolluri SK, Wu H, Cao Y, Chen J, Wu Y, Yan T, Cao X, Gao W, Molotkov A, Jiang F, Li WG, Lin B, Zhang HP, Yu J, Luo SP, Zeng JZ, Duester G, Huang PQ, Zhang XK. NSAID sulindac and its analogs bind RXRa and inhibit RXRa-dependent AKT signaling. Cancer Cell. 2010; 17(6):560-73.

39. Xu D, Cai L, Guo S, Xie L, Yin M, Chen Z, Zhou H, Su Y, Zeng Z, Zhang X. Virtual screening and experimental validation identify novel modulators of nuclear receptor RXRa from Drugbank database. Bioorg Med Chem Lett. 2017;27:1055-61.

40. Meng PJ, Lin J, Liu LL. Aquatic organotin pollution in Taiwan. J Environ Manag. 2009;90(Suppl 1):S8-15.

41. Fu CT, Wu SC. Seasonal variation of the distribution of PCBs in sediments and biota in a PCB-contaminated estuary. Chemosphere. 2006;62:1786-94.

42. Zuo Z, Wang C, Wu M, Wang Y, Chen Y. Exposure to tributyltin and triphenyltin induces DNA damage and alters nucleotide excision repair gene transcription in Sebastiscus marmoratus liver. Aquat Toxicol. 2012;122123:106-12.

43. Chen D, Kannan $K$, Tan H, Zheng Z, Feng YL, Wu Y, Widelka M. Bisphenol analogues other than BPA: environmental occurrence, human exposure, and toxicity-a review. Environ Sci Technol. 2016;50(11):5438-53.

44. Varanasi U, Brown DW, Hom T, Burrows DG, Sloan CA, Field LJ, Stein JE, Tilbury KL, McCain BB, Chan S. Survey of Alaskan subsistence fish, marine mammal, and invertebrate samples collected 1989-91 for exposure to oil spilled from the Exxon Valdez..1993; vol. 1. NOAA Technical Memorandum NMFS-NWFSC-12. https://www.nwfsc.noaa.gov/publications/scipubs/ techmemos/tm12/tm12.htm

45. Oliva AL, La Colla NS, Arias AH, Blasina GE, Lopez Cazorla A, Marcovecchio JE. Distribution and human health risk assessment of PAHs in four fish species from a SW Atlantic estuary. Environ Sci Pollut Res Int. 2017;24(23): 18979-90.

46. Bandowe BA, Bigalke M, Boamah L, Nyarko E, Saalia FK, Wilcke W. Polycyclic aromatic compounds (PAHs and oxygenated PAHs) and trace metals in fish species from Ghana (West Africa): bioaccumulation and health risk assessment. Environ Int. 2014;65:135-46.

47. Frapiccini E, Annibaldi A, Betti M, Polidori P, Truzzi C, Marini M. Polycyclic aromatic hydrocarbon (PAH) accumulation in different common sole (Solea solea) tissues from the North Adriatic Sea peculiar impacted area. Mar Pollut Bull. 2018;137:61-8.

48. Sogbanmu TO, Osibona AO, Otitoloju AA. Specific polycyclic aromatic hydrocarbons identified as ecological risk factors in the Lagos lagoon, Nigeria. Environ Pollut. 2019;255(Pt 2):113295.

49. León VM, García I, Martínez-Gómez C, Campillo JA, Benedicto J. Heterogeneous distribution of polycyclic aromatic hydrocarbons in surface sediments and red mullet along the Spanish Mediterranean coast. Mar Pollut Bull. 2014;87(1-2):352-63.

50. Ohiozebau E, Tendler B, Codling G, Kelly E, Giesy JP, Jones PD. Potential health risks posed by polycyclic aromatic hydrocarbons in muscle tissues of fishes from the Athabasca and slave Rivers, Canada. Environ Geochem Health. 2017;39(1):139-60.

51. Flesher JW, Lehner AF. Structure, function and carcinogenicity of metabolites of methylated and non-methylated polycyclic aromatic hydrocarbons: a comprehensive review. Toxicol Mech Methods. 2016; 26(3):151-79.

52. Lam MM, Bülow R, Engwall M, Giesy JP, Larsson M. Methylated PACs are more potent than their parent compounds: A study of aryl hydrocarbon receptor-mediated activity, degradability, and mixture interactions in the H4IIE-luc assay. Environ Toxicol Chem. 2018;37(5):1409-19.

53. Lam MM, Engwall M, Denison MS, Larsson M. Methylated polycyclic aromatic hydrocarbons and/or their metabolites are important contributors to the overall estrogenic activity of polycyclic aromatic hydrocarboncontaminated soils. Environ Toxicol Chem. 2018;37(2):385-97.

\section{Publisher's Note}

Springer Nature remains neutral with regard to jurisdictional claims in published maps and institutional affiliations.
Ready to submit your research? Choose BMC and benefit from:

- fast, convenient online submission

- thorough peer review by experienced researchers in your field

- rapid publication on acceptance

- support for research data, including large and complex data types

- gold Open Access which fosters wider collaboration and increased citations

- maximum visibility for your research: over $100 \mathrm{M}$ website views per year

At $\mathrm{BMC}$, research is always in progress.

Learn more biomedcentral.com/submissions 